\title{
Can the operating time be reduced by use of magnification in Total Thyroidectomy? A preliminary Study.
}

\author{
RW seneviratne ${ }^{1}$, MMAJ Kumara ${ }^{1}$, R Abeywickrama ${ }^{1}$, JPM Kumarasinghe ${ }^{1}$, PV De Silva ${ }^{2}$
}

\begin{abstract}
Introduction: Total thyroidectomy is a major surgical procedure which is becoming increasingly popular. Operating Time taken for total thyroidectomy can be approximately 3- 4 hours. Thyroidectomy surgeries still occupy a significant portion of busy general surgical lists in high volume thyroid centers such as Surgical Professorial Unit of Teaching Hospital Karapitiya. With resource constrains this implies much theatre time, staff and costs with significant bearing on health care demands. Reduction in operating time with consequent reduction in time under anesthesia is beneficial to patient too. This study was carried out to explore whether the surgical time is reduced by using magnification by the surgeon for total thyroidectomy.
\end{abstract}

Methods: The operating procedure of total thyroidectomy was divided in to 10 phases for the purpose of study. Surgeon A, who has been doing thyroid surgery for last 10 years without any magnification, was selected as the object of the study. Three total thyroidectomies performed by surgeon $A$ was observed and records were made by surgeon B for timing of each phase and for any other significant events occurred during the operation. Surgeon A has been using magnification for next 10 thyroidectomies which allowed him to get over the steepest part of the learning curve. This was not included in the study. Subsequently surgeon A performed 14 thyroidectomies over next two months and 11 of them were observed by the other surgeon $\mathrm{B}$.

Results: Results of the three observed thyroidectomies done without magnification: Control Group (CG) was compared with the group in which thyroidectomies were done under magnification: Study Group (SG). There were no significant difference between SG and CG with regard to time taken during the path from skin incision to isthmus (S1). During the dissection over anterolateral surface of the left lobe (S2) significant difference was observed with CG gaining 1.91 minute average time advantage. More deliberations were observed over small strands containing minute blood vessels which were usually dissected bluntly in CG. Total operating time (Skin to skin) was 109.76 minutes for SG and 146.67 for CG.

1. Senior Lecturer, Department of Surgery, Faculty of Medicine, University of Ruhuna

2. Senior Lecturer, Department of Community Medicine, Faculty of Medicine, University of Ruhuna
Conclusion: The study shows that approximately 45 minute reduction in operating time can be achieved with use of loupes. This preliminary study has given an insight in to how and why operating time for total thyroidectomy can be reduced by the use of loupe magnification

\section{Introduction}

Total thyroidectomy a major procedure is becoming increasingly popular over limited resections for diffuse thyroid disease whether it is benign or malignant. The risk of complications such as external laringial nerve palsy, recurrent laringial nerve palsy and hypoparathyroidism minimized with meticulous surgical technique has shifted the choice from subtotal surgical procedures to total thyroidectomy (1). Removal of the diseased gland avoids the requirement of a completion procedure in case of post operative cancer findings or late recurrence which is fraught with complications such as recurrent laryngial nerve damage. High volume thyroid centers conventionally defined as a unit which does over 100 total thyroidectomies a year naturally allow surgeons to acquire high degree of technical skills and experience with minimal complications(2). Professorial surgical unit of teaching hospital, Karapitiya, Galle (THK) is such a centre owing to high prevalence of thyroid disease in Galle district, the catchment area. Total thyroidectomies are performed by general surgeons in keeping with local practice. Operating Time taken for total thyroidectomy can be approximately 3- 4 hours according to many studies (3) but it could be lower in a high volume centre. However thyroid surgery still occupies a significant portion of busy general surgical lists. With resource constrains this implies much theatre time, staff and costs with significant bearing on health care demands. Reduction in operating time with consequent reduction in time under anesthesia is beneficial to patient as significant number of them have at least one co morbid condition which can potentially lead to post operative complications. It is also benefit those waiting for other operations especially shorter ones such as hernia repair as 3-4 of them can be accomplished within a time taken for total thyroidectomy.

Few studies are available assessing the impact on operating time when using the loupe magnification and none in relation to thyroid surgery. An original research article by saber et al (2010) recognize the incidence of reduced complications on using simple binocular loupe with magnification of 2.5(4)Therefore a preliminary(pilot) 
study was designed to assess the impact of using loupe magnification on operating time without compromising safety and other factors.

\section{Objective of the study}

This study was carried out with the objective of determine the overall operating time for total thyroidectomy reduced by surgeon using magnification and which stages of the operation where the magnification have an impact.

\section{Methodology}

The operating procedure of total thyroidectomy was divided in to 10 phases for the purpose of study.

\begin{tabular}{|c|c|c|c|}
\hline Phases & From & To & Remarks \\
\hline S1 & Commencing skin incision & Reaching Thyroid isthmus & \\
\hline S2 & Reaching Thyroid isthmus & $\begin{array}{l}\text { End of Dissecting anteromedail } \\
\text { surface of left lobe of thyroid }\end{array}$ & $\begin{array}{l}\text { Include isolation and ligation of left } \\
\text { middle thyroid vein }\end{array}$ \\
\hline S3 & $\begin{array}{l}\text { End of Dissecting over } \\
\text { anterolateral surface of } \\
\text { left thyroid lobe }\end{array}$ & $\begin{array}{l}\text { End of Isolation and ligation of } \\
\text { superior pole }\end{array}$ & \\
\hline S4 & $\begin{array}{l}\text { Isolation and ligation of } \\
\text { superior pole }\end{array}$ & $\begin{array}{l}\text { Identification of left recurrent } \\
\text { laryngeal nerve }\end{array}$ & \\
\hline S5 & $\begin{array}{l}\text { Identification of left recur- } \\
\text { rent laryngeal nerve }\end{array}$ & $\begin{array}{l}\text { Lifting of the hemi thyroid away } \\
\text { from recurrent laryngeal nerve } \\
\text { and across half of the anterior } \\
\text { surface of the trachea. }\end{array}$ & Include ligation of inferior pole \\
\hline S6 & $\begin{array}{l}\text { Commencing dissection } \\
\text { over anterolateral surface } \\
\text { of right thyroid lobe }\end{array}$ & $\begin{array}{l}\text { End of dissection over anterolat- } \\
\text { eral surface of right lobe }\end{array}$ & $\begin{array}{l}\text { Include isolation and ligation of left } \\
\text { middle thyroid vein }\end{array}$ \\
\hline S7 & $\begin{array}{l}\text { End of dissection over } \\
\text { anterolateral surface of } \\
\text { right lobe }\end{array}$ & $\begin{array}{l}\text { End of isolation and ligation of } \\
\text { right superior pole }\end{array}$ & \\
\hline S8 & $\begin{array}{l}\text { Isolation and ligation of } \\
\text { right superior pole }\end{array}$ & $\begin{array}{l}\text { Detection of right recurrent } \\
\text { laryngeal nerve }\end{array}$ & Include ligation of right inferior pole. \\
\hline S9 & $\begin{array}{l}\text { Detecting right recurrent } \\
\text { laryngeal nerve }\end{array}$ & $\begin{array}{l}\text { Lifting of right lobe away from } \\
\text { recurrent laryngeal nerve and } \\
\text { removal of the gland }\end{array}$ & \\
\hline S10 & $\begin{array}{l}\text { Lifting of right lobe away } \\
\text { from recurrent laryngeal } \\
\text { nerve and removal of the } \\
\text { gland }\end{array}$ & $\begin{array}{l}\text { End of the closure of skin inci- } \\
\text { sion }\end{array}$ & \\
\hline
\end{tabular}

Surgeon A, who has been doing thyroid surgery for last 10 years without any magnification was selected as the object of the study. Three total thyroidectomies performed by surgeon $A$ was observed and records were made by surgeon $B$ for timing of each phase and for any other significant events occurred during the operation. Surgeon A has been using magnification for next 10 thyroidectomies which allowed him to get over the steepest part of the learning curve. This was not included in the study. Subsequently surgeon A performed 14 thyroidectomies over next two months and 11 of them were observed by the other surgeon B. Surgeon B could not attend to other 3 due to work commitments. At the end of each operation surgeon $A$ and $B$ had a reflective discussion and recorded key issues which were later discussed together with surgeons $C$ and $D$, two experienced general surgeon.

\section{Results}

Results of the three observed thyroidectomies done without magnification: Control Group (CG) were compared with the group in which thyroidectomies were done under magnification: Study Group (SG). 
Table 1- Study Group (SG)

\begin{tabular}{|c|c|c|c|c|c|c|c|c|c|c|c|c|c|c|}
\hline phases & start & end & 1 & 2 & 3 & 4 & 5 & 6 & 7 & 8 & 9 & 10 & 11 & $\begin{array}{l}\text { TOT } \\
\text { study }\end{array}$ \\
\hline S1 & $\begin{array}{l}\text { Starting skin } \\
\text { incision }\end{array}$ & Thyroid isthmus & 14 & 12 & 15.5 & 17 & 13.5 & 15 & 13 & 15 & 16 & 16.5 & 14 & 14.68 \\
\hline S2 & $\begin{array}{l}\text { Thyroid isth- } \\
\text { mus }\end{array}$ & $\begin{array}{l}\text { End of } \\
\text { Dissection } \\
\text { anteromedeal } \\
\text { surface of left } \\
\text { lobe of thyroid }\end{array}$ & 8 & 7.5 & 8 & 8.5 & 6 & 6 & 5.5 & 8.5 & 9 & 8 & 6.5 & 7.409 \\
\hline S3 & $\begin{array}{l}\text { End of } \\
\text { Dissection an- } \\
\text { teromedeal } \\
\text { surface of } \\
\text { thyroid gland }\end{array}$ & $\begin{array}{l}\text { End of Isolation } \\
\text { of superior pole }\end{array}$ & 6 & 6.5 & 6 & 6.5 & 6.5 & 7 & 6 & 5.5 & 7 & 6 & 6.3 & 6.3 \\
\hline S4 & $\begin{array}{l}\text { Isolation of } \\
\text { superior pole }\end{array}$ & Detecting RLN & 5 & 6 & 5 & 6 & 5 & 4 & 3.5 & 4 & 3.5 & 4 & 4 & 4.54 \\
\hline S5 & $\begin{array}{l}\text { Detecting } \\
\text { RLN }\end{array}$ & $\begin{array}{l}\text { Lifting of the } \\
\text { hemi thyroid } \\
\text { away from RLN } \\
\text { and across half } \\
\text { of the anterior } \\
\text { surface of the } \\
\text { trachea. }\end{array}$ & 17 & 18 & 16 & 17.5 & 18 & 19.5 & 19 & 19 & 20 & 21 & 18.5 & 18.5 \\
\hline S6 & $\begin{array}{l}\text { Starting } \\
\text { dissection of } \\
\text { anterolateral } \\
\text { surface of } \\
\text { right lobe }\end{array}$ & $\begin{array}{l}\text { End of } \\
\text { dissection of } \\
\text { anterolateral } \\
\text { surface of right } \\
\text { lobe }\end{array}$ & 7.5 & 7 & 7 & 6.5 & 6.5 & 7 & 6 & 7.5 & 6 & 6.5 & 5.5 & 5.636 \\
\hline S7 & $\begin{array}{l}\text { End of } \\
\text { dissection of } \\
\text { anterome- } \\
\text { deal surface } \\
\text { of right lobe }\end{array}$ & $\begin{array}{l}\text { End of isolation } \\
\text { of right superior } \\
\text { lobe }\end{array}$ & 7 & 6 & 6.5 & 7 & 6 & 6 & 6.5 & 6.5 & 7.5 & 6 & 6.5 & 6.5 \\
\hline S8 & $\begin{array}{l}\text { Isolation of } \\
\text { right superi- } \\
\text { or pole }\end{array}$ & $\begin{array}{l}\text { End of Isolation } \\
\text { of right superior } \\
\text { pole }\end{array}$ & 9 & 9 & 9 & 8 & 7.5 & 8 & 9 & 9.5 & 8 & 9 & 8.5 & 8.590 \\
\hline S9 & $\begin{array}{l}\text { Detecting } \\
\text { right RLN }\end{array}$ & $\begin{array}{l}\text { Detecting right } \\
\text { RLN }\end{array}$ & 16 & 17 & 17.5 & 15.5 & 18 & 19 & 17 & 16.5 & 18 & 19.5 & 17.5 & 17.40 \\
\hline \multirow[t]{2}{*}{ S10 } & $\begin{array}{l}\text { Lifting of } \\
\text { hemi thyroid } \\
\text { away from } \\
\text { RLN and re- } \\
\text { moval of the } \\
\text { gland }\end{array}$ & $\begin{array}{l}\text { Lifting of the } \\
\text { hemi thyroid } \\
\text { away from RLN } \\
\text { and removal of } \\
\text { the gland }\end{array}$ & 18 & 20.5 & 20 & 21.5 & 18.5 & 19 & 20.5 & 17.5 & 17.5 & 18.5 & 19.5 & 19.18 \\
\hline & & & & & & & & & & & & & & 109.75 \\
\hline
\end{tabular}


Table 2 - Control Group (CG)

\begin{tabular}{|c|c|c|c|c|c|c|}
\hline Stages & Start & End & P1 & $\mathbf{P 2}$ & P3 & Average \\
\hline S1 & $\begin{array}{l}\text { Commencement of skin } \\
\text { incision }\end{array}$ & Reaching Thyroid isthmus & 14 & 15 & 17 & 15.333 \\
\hline S2 & Thyroid isthmus & $\begin{array}{l}\text { End of Dissection antero lateral surface } \\
\text { of left lobe of thyroid }\end{array}$ & 5 & 6 & 5.5 & 5.5 \\
\hline S3 & $\begin{array}{l}\text { End of Dissection } \\
\text { anteromedail surface } \\
\text { of thyroid gland }\end{array}$ & End of Isolation of superior pole & 5 & 5 & 6 & 5.333 \\
\hline S4 & $\begin{array}{l}\text { Isloation of superior } \\
\text { pole }\end{array}$ & Detecting RLN & 10 & 9.5 & 11.5 & 10.333 \\
\hline S5 & Detecting RLN & $\begin{array}{l}\text { Lifting of the hemi thyroid away from } \\
\text { RLN and across half of the anterior } \\
\text { surface of the trachea. }\end{array}$ & 32 & 32.5 & 33.5 & 33.333 \\
\hline S6 & $\begin{array}{l}\text { Strating dissection of } \\
\text { anterolateral surface of } \\
\text { right lobe }\end{array}$ & $\begin{array}{l}\text { End of dissection of anterolateral surface } \\
\text { of right lobe }\end{array}$ & 5.5 & 4.5 & 5 & 5 \\
\hline S7 & $\begin{array}{l}\text { End of dissection of } \\
\text { anterolateral surface of } \\
\text { right lobe }\end{array}$ & End of isolation of right superior lobe & 4.5 & 5 & 5 & 4.833 \\
\hline S8 & $\begin{array}{l}\text { Isloation of right } \\
\text { superior pole }\end{array}$ & End of Isloation of right superior pole & 15.5 & 16.5 & 15 & 15.666 \\
\hline S9 & Detecting right RLN & Detecting right RLN & 30 & 29.5 & 33 & 30.833 \\
\hline \multirow[t]{2}{*}{ S10 } & $\begin{array}{l}\text { Lifting of hemi thyroid } \\
\text { away from RLN and } \\
\text { removal of the gland }\end{array}$ & $\begin{array}{l}\text { Lifting of the hemi thyroid away from } \\
\text { RLN and removal of the galnd }\end{array}$ & 18 & 22.5 & 21 & 20.5 \\
\hline & & & & & & 146.666 \\
\hline
\end{tabular}

There was no significant difference between SG and CG with regard to time taken during the path from skin incision to isthmus (S1). During the dissection over anterolateral surface of the left lobe (S2) significant difference was observed with CG gaining 1.91 minute average time advantage. More deliberations were observed over small strands containing minute blood vessels which were usually dissected bluntly in CG. On two occasions under magnification the dissection went beyond required margins in superior and lateral directions. Proceeding from there to isolation of superior pole (S3) saw CG ahead of SG by approximately one minute. In S4 stage the SG detected left recurrent laryngeal nerve in 4.55 minutes compared to 10.33 taken by CG. Clearance of left recurrent laryngeal nerve and lifting left lobe off the trachea in stage S5 took SG only 18.5 minutes compared to 33.33 taken by CG. More clear tissue separation and less bleeding requiring ligation were marked in SG especially near cricoid.

SG took $6.63 \mathrm{~min}$ compared to $5 \mathrm{~min}$ in CG for dissection over right anterolateral surface (Stage S6) completing task in less time compared to their left euivalant (S2). Some deliberations over minute strands which were usually managed with speedy blunt dissection were noted in SG. Isolation of right superior pole (stage S 7) took 6.5 minutes in SG compared to 4.8 in CG .Although clearance around pole was easy and bloodless ligation was difficult with surgeon struggling and looking over loupes some times. Detection of right recurrent laryngeal nerve was completed with confidence in 8.59 by SG compared to 15.67 by CG in stage $S 8$ while clearance of gland off nerve and trachea (stage $S$ 9) took only 17.41 in SG compared to 30.83 in CG. It was noted that CG required following many different strands before detecting the nerve and separation of nerve off the gland was technically difficult compared to left side for both groups. Variable position of right nerve was also a factor. Closure stage (S10) took almost the same time for both groups ( SG 19.18 compared to CG 20.5)

Total operating time (Skin to skin) was 109.76 minutes for SG and 146.67 for CG.

\section{Discussion}

Operating time is a much sort after and expensive commodity in developed countries. Major and major complex operations can take up long procedure times especially due to fact that they have many critical steps. Long operating times can have an adverse impact on patients undergoing surgery due to potential morbidity incurred by prolonged anesthetic time and co morbid 
conditions. Long operations can also deprive many patients awaiting minor operations of their slots in the list. Health care system should always be in the lookout for means to reduce procedure time which will benefit the patients, other patients as well as the health care system. Any surgeon is allowed to use loupe magnification in any procedure he chose to perform. Use of loupe magnification in surgery is recommended for microsurgical procedures such as repair of digital artery or facial nerve in developing countries as an alternative for expensive microscopic surgery(5). Operating microscope give magnification between six and 40 times. High powered loupes gives magnification between four and six while low powered loops offer between 2.5 and four. In addition to this much accepted role they are used by more imaginative and enterprising surgeons for wide range of tasks. Emergency clinicians have used magnification in wound debridement and suturing of facial and hand wounds (6). A comparative study of time taken for Free microvascular tissue transplantation in head using microscope and loupes have shown that operating time is shorter in loupes group(7). Bernstein et al (2013) has shown that microscope gives four times better results than loupe in digital nerve repair(8).They also showed that surgeon, his training, repair time or sutures used did not have any significant impact on the outcome, a proof of importance in magnification. Pieptu and Luchian( 2003) recommend loupes for "macromicrosurgery" procedures such as reimplantations down to palmer arch and for free flaps with vessels over 1.5 $\mathrm{mm}$. However they also recommend that the surgeon should be proficient in microscope aided microsurgical procedures beforehand(9). The loupes should preferably be custom made with adjustments for interpupillary distances and corrected vision (10)

Total operating time for total thyroidectomy in SG is 109 minutes (approximately one hour and forty five minutes) compared to 147 (nearly two and half hours) clearly a significant finding even in a preliminary study.

Stage 1 to reach thyroid isthmus include mostly traction separation and blunt dissection and in a very well defined tissue plain beneath the platysma. Magnification, not surprisingly has not made much of a difference in time. Stage 2, the dissection over anterolateral surface of left lobe has taken more time for SG due to noted deliberations. Magnification make minute vessels bigger which make surgeon somewhat hesitate to cut in order to prevent significant bleeding. This adds to operating time. Similar phenomenon can make surgeons apprehensive about blood vessels and bleeding encountered during laparoscopic surgery. It is also noted in two operations that stage 2 dissection shifted beyond the limits required. The surgeon's desire for global view periodically while operating through loupes makes him look through and over the loupes which adds to operating time. If he stays constantly in the focused view it can lead to errors in dissection including going beyond limits. Stage 3 and stage 7 separating the superior poles on either side does not show much time difference between two groups. It is likely that time saved by ease of clearance in magnified view was balanced by struggling to ligate which require more global view in SG.

The critical step in the whole procedure is finding the recurrent laryngeal nerves and dissecting the gland off it. This has led to stages of detecting and dissecting nerve off the gland take more time than any other part of the operation. Stages 4 and 8 involved detecting recurrent laryngeal nerve. Advantage of magnification was much evident with SG group gaining advantage of lesser time i.e. 4.55 to 10.33 on left and 8.59 to 15.67 on right. Overall it has taken more time to detect the nerve on right which is due to oblique angle providing variations in lay of the right nerve. Individual variations in anatomy of critical structures take more time to find them which is further increased by surgeon's apprehension. Stages 5 and 9 of lifting the lobes off the nerves with careful dissection while avoiding bleeders gives a clear advantage to magnification group maintain 17.41 as opposed to 30.83 of CG. Observation- orientation- decision- action cycle (OODI or Boyd cycle) , first described by Colonel John Boyd of United States Airforce in 1953 has provided the framework functioning and improvement of many manufacturing, service or administrative processes(11). Improvement of efficiency if defined as the progress divided by time taken, in a process such as piloting a plane to a destination or completing a surgical operation can be achieved by reducing the time taken for any components of the cycle. Reverse is also true. If the time taken for a process is reduced through a change which was deliberate or inadvertent thus improving efficiency, a critical analysis should be made to find what has made the difference at which stage which has given the favored outcome. In this study comparing SG and CG, it is clear that significant time advantages gained by SG with improved observation via loupes in stages of 4,5,8 and 9 has more than offset the comparative time disadvantages in certain other steps. Stages where impact of observation is minimal showed no significant difference in comparison.

Surgeon's posture was better in SG although periodic adjustments to clear the lenses and maintain a constant gap between the lenses and operating field added some procedure time during many stages. It was also noted that struggling with ligation of structures and certain gross movements were more in SG group due to reduced global vision. 


\section{Conclusion}

The study shows that approximately 45 minute reduction in operating time can be achieved with use of loupes. This preliminary study has given an insight in to how and why operating time for total thyroidectomy can be reduced by the use of loupe magnification .This reduction is achieved by shortening time taken to identify recurrent laryngeal nerve and also that taken to dissect the gland off it i.e during the most critical stages of the procedure. Loupe does not make significant time differences to other stages of the operation and sometimes even lengthen them. Effects of loupe magnification on operating time should be studies across variety of operations in a wider study and use of them should be encouraged in operations or stages of operation where it will give a time advantage.

\section{References}

1. Efficacy and safety of total thyroidectomy in the management of benign thyroid disease: a review of 932 cases Efremidou El, Papageorgiou MS, Liratzopoulos N, Manolas KJ, Can J Surg. 2009 Feb; 52(1): 39-44.

2. Volume-Based Trends in Thyroid Surgery .Gourin CG, Tufano RP, Forastiere AA, Koch WM, Pawlik TM, Bristow RE. Arch Otolaryngol Head Neck Surg. 2010;136(12):1191-1198.

3. Factors Influencing the Length of the Incision and the Operating Time for Total Thyroidectomy Consorti F, Milazzo F, Notarangelo M, Scardella L, Antonac A. BMC Surg. 2012;12(15)
4. Total Thyroidectomy by loop magnification. a comparative study Saber A, Riffat M doi.10. 1007, s10353-011-0591-0 2010

5. The Use of Loupe Magnification In Microsurgery In The Third World: A Trinidad Experience Ragbir M, Ali T, Naraynsingh V, Ramdass M, Romany S, Mohammed $\mathrm{F}$

6. The value of loupe magnification: an underused tool in emergency medicine. Hart RG1, Hall J.PMID: 17606097

7. Use of the operating microscope and loupes for head and neck free micro vascular tissue transfer: a retrospective comparison. Ross DA, Ariyan S, Restifo R, Sasaki CT.PMID:12578447

8. Comparison of magnification in primary digital nerve repair: literature review, survey of practice trends, and assessment of 90 cadaveric repairs. Bernstein DT, Hamilton KL, Foy C, Petersen NJ, Netscher DT. J Hand Surg Am. 2013 Nov;38(11):2144-50.

9. Loupes-only microsurgery .Pieptu D, Luchian S.PMID:12833317

10. Refinement on Surgical Technique: Role of Magnification. A. Mungadiper -identifying time for total thyroidectomy

11. Understanding of OODA Loops, A Cognitive Hierarchy and Object-Oriented Analysis and Design. Curts RJ, Lane IH, Campbell DE, 